\title{
The Bottom Of The Pyramid: Key Roles For Businesses
}

Mohsin Habib, University of Massachusetts - Boston, USA

Leon Zurawicki, University of Massachusetts - Boston, USA

\begin{abstract}
The poor at the Bottom of the Pyramid (BOP) has traditionally been viewed as an unattractive segment for businesses. The lack of interest has led to various proposals to increase company participation. At the same time there is also a renewed focus on how to reduce or eliminate poverty. Companies are asked to seriously consider both objectives: making a profitable operation and eradicating poverty. For businesses, the poor can be viewed as consumers, suppliers, and employees. Each of these areas presents different challenges which are discussed. Finally, recommendations are presented to address the issues and to make the companies more effective.
\end{abstract}

Keywords: Poverty, Corporate Social Responsibility, Sustainable Development.

\section{INTRODUCTION}

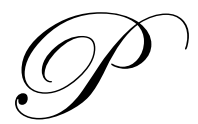

overty is a disgrace to humanity, especially when viewed in the context of huge inequalities of the standard of living between and within the countries. To reduce the poverty is a noble task and the key to sustainable development. The problem has never been so severe before and the political pressure is very high. Governments alone cannot resolve the problem through own economic and income redistribution policies. At the same time, the corporate world has become more sensitive to the issues of social responsibility in general and the concerns of the poor in particular. There is obviously much more to do when we realize that altogether 4 billion people on earth starve on less than $\$ 2$ per day (Kim Hak-Su, 2004), with all the dire consequences in terms of the quality and longevity of life.

The government in a country is the most powerful actor for generating and distributing the tax income. But it still needs an ally in order to fulfill its poverty-reduction mission. Except for a few countries, the states today do not get involved in the bulk of economic activities and the wealth is created foremost through the private business sector. Thus, a concerted effort involving the government, private businesses, non-governmental organizations (NGOs) and trade unions can only prove beneficial.

The concept of Corporate Social Responsibility (CSR) has evolved during the past 40 years with respect to the society's expectations of the role of business and its eagerness to go beyond the strict compliance with the laws (Schwartz and Carroll, 2003). It appears that the willingness to develop a desirable image of a good corporate citizen (with all of its beneficial implications) becomes the main driver of the CSR (UNDP/BC/CII/PwC, 2002). Whether the corporate world is going to adopt a more deontological approach to CSR and transplant the social values in the private business, remains however to be seen (De George, 1999).

Large multinational corporations (MNCs) have traditionally been selling in the vast and rich national markets and did not need to consider the countries and regions marked by poverty. However, in the present stage of globalization and increased international competition, that perspective is changing. At the end of January 2005, some distinguished speakers at the Davos World Economic Forum such as Jacques Chirac, Tony Blair, and Bill Gates clearly focused on global poverty (WEF, 2005). More importantly, for the first time in the history of the prestigious meeting, poverty was voted the number one global priority issue to be addressed. 
The United Nations Millennium Development Goal specifically call for the reduction of poverty worldwide. The specific goal is to cut the number of people living on less than $\$ 1$ per day by half from 1990 to 2015 (UN, 2006). In order to achieve this ambitious goal it is imperative that the private sector does its fair share. The Bottom of the Pyramid (BOP) model (Prahalad, 2004) builds on this idea suggesting major business opportunities for the private sector in the poorest segment of the population. To combine the concept of business opportunity with poverty alleviation we believe that a more holistic perspective is needed. The business motive must be combined with the corporate social responsibility motive. Also, the issue of sustainability becomes important while addressing poverty in some of the world's most concentrated population centers. Sustainable development is defined as "development that meets the needs of the present without compromising the ability of future generations to meet their own needs" (WCED, 1987: 43). This means a need to preserve the basic resources for successive generations and to make necessary socio-economic adjustments in the short run. Hahn (2008) presents the Rawlsian principles of justice as motivation for sustainable development at the BOP. The primary focus is on equal freedom and to make sure that the action taken are for everyone's advantage. Like NGOs, companies can influence the government to promote the rights of the poor (Hahn, 2008) and in this manner even strengthen the democratic foundation (Bird and Smucker, 2007).

The demand in the BOP market is for both consumer and industrial goods as production continues to increase in that segment. There are opportunities for direct investments as well (The World Bank, 2004). Others have suggested that there are opportunities for both production and procurement in the BOP segment (Karnani, 2007). The poor can join the global integrated value chain as small producers and suppliers for larger companies. This can give them access to other markets (UNCTAD, 2007).

In this paper, we explore where and how the government priorities and corporate responsibilities should interplay. The goal is to conceptually highlight the key areas of possible cooperation between the government and the business, less so the practicalities thereof. The two principles we want to emphasize will be (a) the clarity of positions and expectations and (b) the parity and reciprocity between the two parties.

In terms of singling out the most burning issues the spotlight will be on:

1. Marketing and selling the products to the poor. The concept is a challenge for free market capitalism but still potentially a profitable proposition.

2. The poor as suppliers.

3. The poor as employees.

The first aspect will be treated here from a marketing standpoint, while the second and the third call for a managerial perspective.

\section{THE POOR AS CONSUMERS}

Studies in consumer behavior typically focus on the households who live above the poverty line and enjoy the luxury of a considerable choice in buying. Much less attention has been paid to the "have-not's" (Shultz, 2001). As a result, there are very few studies addressing the spending pattern at the stage of deprivation. This is the result of the "Western" thinking about consumption with the emphasis on stimulating new needs as opposed to satisfying the essential ones. Hence, the sophistication and the purchasing power of the affluent consumers is the main driver of the marketing policies of the corporations headquartered in the developed countries. Western MNCs extend such strategies globally to less developed and developing markets. In case of extremely destitute countries (e.g. parts of Africa), the MNCs limit their operations to the minimum.

The sheer huge number of the households with extremely low income reflects substantial virtual demand at least for bare necessities (Pralahad, and Hammond. 2002). However, meeting this demand requires a significant change in companies' approach. In some cases, the companies may have to make the consumers aware of the "hidden" needs first (e.g. safe, treated water for drinking and other household purposes) before offering them the necessary products. 
The cost to serve the poor can be quite high. Even though there is a trend for the poor to migrate to the urban areas for jobs there still remains a significant portion in dispersed rural areas. These areas, as is so often the case, are less developed within the economy and lacks proper infrastructure (roads, bridges, communication, etc.). Getting to the poor can be a difficult task requiring considerable resources, manpower and time. Targeting the poor as potential customers should be carefully examined because most of their daily income, as high as $80 \%$ (Karnani, 2007), is spend on basic items (food, clothing and shelter). There is simply not enough disposable income for other "luxury" items.

\section{Designing the right products}

Typically, the value orientation by the poor is more focused on price as opposed to quality of the whole spectrum of products and services. It follows that the quality-price relationship is shaped differently in the minds of the "have-nots" in contrast to the more affluent buyers. To exploit them, the international product line managers need to follow a strategy different from the present one. The offer addressed to the poor customers needs to center on the usefulness and affordability of the essential products and services. Furthermore, the appropriate product design needs to be accompanied by greater emphasis on consumer education. The enhanced marketing effort directed to poor consumers should educate how to use the products sparingly and efficiently, how to extend the durability, and even how to "perform-it-yourself" such functions as maintenance and service. At the same time, the psychological need espoused by the poor consumers who do not wish to be confined to secondary categories of products and services, deserves attention. By extending their brand names to well-designed and well-built basic products, the icons of global business gain the opportunity to increase the satisfaction of the poor customers. Will they do this? It poses a big challenge for the boardrooms which may fear "diluting" the brand. Equally important is the competence gap. Even when the Western companies are willing to target the poor in the developing countries, they often lack market intelligence and/or distribution channels. The preponderant point is to learn more.

Thus, in marketing terms the key issues to consider are:

1. Do we understand the real needs of the poor consumers as they pertain to our type of offerings? How do we identify prospective poor customers? Do we need to segment them?

2. Do we have the right products/services to offer?

3. How do we ensure that there is sufficient demand for our products/services to make our new offering venture economically viable?

4. How do we help our customers to afford our products?

5. How do we reach our customers?

6. How do we collect revenues?

7. How can we best design our supply chain?

One way to learn is through tapping into local networks and local knowledge. This will hopefully reveal to what extent catering to the poor requires a revision of the typical Western approach which emphasizes the importance of the brand and the new ever more sophisticated offerings. If the poor are, by definition, more rational and intrinsic value-oriented consumers, then another emerging challenge is how to convey the relevant information and experience to mostly illiterate audience.

To comprehensively comment on the above issues warrants writing another paper. Here we only wish to point to strategic options. In a simple framework, stripping down the "deluxe" versions of existing products of the less essential features is one option. This kind of strategy could produce "people's computer" as much as "people's car." The process can be possibly extended to items like footwear or food supplements.

On a different note, the global trade in pre-owned goods -- clothing and household appliances -- often discarded at an additional cost in the developed countries represents another avenue to help the poor satisfy their needs. However, in 1999, documented export sales of worn clothing from the U.S. reached only $\$ 217$ million, a miniscule figure compared to the needs of the have-nots (Green, 2001). Indeed, it is a shame that in 2006, 59.6 million computers and televisions would be designated for disposal in the US alone (Erle, 2004) when the needy are 
deprived of using them. Not to mention millions of toys discarded each year in the Western world. Whether this is the area of activity suitable for established multinationals, typically involved in marketing of new products, is open for discussion.

In sum, the viable solutions boil down to three mutually non-exclusive suggestions:

1. Drop the prices quoted in the developing countries to the rock-bottom level.

2. Simplify and "cheapify" what you already have.

3. Design from scratch specific offerings geared to the poor.

\section{Stretching the purchasing power}

Allowing the poor to manage and stretch their limited budgets is yet another challenge to boost the sales and cater to the worse-off customers. Naturally, the banking industry has a primary role to play. However, before getting into the credit facilitation issues, there are strategies to pursue more vigorously by the marketers themselves.

Prahalad (2004) suggest that small packages (like shampoo in sachets) create convenience and value for the poor. It is argued that the poor cannot afford to buy the standard products but they can buy in small quantities at a time. With some products, this is a straightforward physical process of dividing the product into smaller subunits. Using smaller packaging alleviates the burden of a one-time expense and establishes a "pay-as you consume" system. To that effect, frequent and small orders of products made available through a streamlined and direct distribution system in poor neighborhoods can be effective. Although companies lose economies of scale benefits in this process, with respect to poor customers it may be more than compensated through consistent and long-term repeat sales (WBCSD, 2004). This strategy (involving both manufacturing and retailing) can apply to items like food products, toiletries, cosmetics, and even medications. Smaller packaging is convenient and helps the poor to manage their cash flow better but whether it actually increases affordability or not has been questioned given that the product price remains the same (Karnani, 2007). Furthermore, using smaller packaging indiscriminately creates an environmental sustainability problem that has not been fully addressed yet. Hence, the overall effects of such a strategy by the companies must be evaluated in depth.

Regarding services, prepayment for ongoing deliveries in small installments (through tokens, prepaid cards or similar mechanisms) can reduce the credit risk and the burden of one large lump sum charges ${ }^{2}$. In addition, successful experiments including incentives to encourage payments (e.g., a discount on the next bill for payment in due time) have been implemented in some countries. Further, viability of a collective billing arrangement allowing the community to make a joint investment and decide how to split the costs among the members could be tested.

While the financial institutions typically take responsibility for providing and facilitating credit, it does not preclude the suppliers of other products and services from offering the same. Especially, the leasing option appears suitable for the customers with poor or no credit history. This could even be more practical since in the case of payment delinquency the re-possessed goods are more easily marketable by the original manufacturer or the retailer than by the provider of the financial credit. Overwhelmingly, the poor of the world live in the countryside and their subsistence depends on farming. Thus, promoting and organizing users' cooperatives and equipment-rental centers (e.g. for agricultural machines) would make business sense. Through the design and mass marketing of low-cost capital equipment in the agricultural sector (e.g. micro-irrigation pump), companies in developing countries have already been able to help the poor grow high value fruits and vegetables and eventually gain access to purchasing power (WBCSD, 2004).

Offering the poor products on credit can create new customers and eradicate poverty. The poor will certainly benefit from such credits because they can buy the product now but unless this product is a productive resource which can generate new income stream for the poor the poverty reduction argument doesn't hold true. In

\footnotetext{
${ }^{1}$ For example, it is not uncommon to see cigarettes sold in some countries in packs of 5 or even per one by the street vendors.

${ }^{2}$ This concept has been successfully implemented by the South African utility company -Eskom.
} 
fact, if anything, buying on credit means in the end the poor will pay more than if they could save and pay in cash later for the consumable (Karnani, 2007). So, while instruments such as micro-credit (discussed below) can pull the poor out of their poverty, credits for buying consumables will not.

\section{Micro-financing and Warranties}

Extending loans to customers with hardly any collateral and a miniscule income which cannot generate any savings poses a tremendous challenge to the credit institutions prospecting the poor. The key issue is to secure payment guarantees in case of default by the primary borrower. Through involvement of the family and other local community members the problem can be alleviated. As an example, the cement company, Cemex, in collaboration with Ashoka ( an NGO specializing in social entrepreneurship) has organized people in small groups in poor Mexican neighborhoods to save money which then can be used to buy building materials and expertise to improve their living conditions. Such company efforts are extremely helpful for the individuals in the group because they can save at lower cost and make faster improvements to their dwellings.

There are some basic issues with micro financing which, unless addressed properly, will limit the impact on the poor. As Akula (2008) mentions, the lack of access to commercial funds, the higher costs of handling large number of micro-transactions, and the absence of scalable operating systems have created barriers for success for the micro-credit organizations. Particularly, the inability to scale operations means at any point in time only a certain number of people will enjoy the benefits of microfinance. For the companies involved, it requires first obtaining additional resources and then using those to gradually roll out offerings to newer customers.

While some companies, such as the famous "Grameen Bank" led by Nobel prize winner Dr. Yunus, have been able to expand their operations significantly, others have not. One solution is to seek the help of capital markets through the structuring of the business in a manner that investors can expect high returns (Akula, 2008). This means, among other things, to consider transferring the organization from a not-for-profit to a for-profit one. Good lines of credit secured from large commercial banks and financial institutions can then make it possible for the firm to turn around and offer thousands of micro-credits to potential customers. Another aspect that should be emphasized is the standardization of products, policies and processes to increase the operational capacity quickly (Akula, 2008). It is also important that employees are knowledgeable about these standard approaches to have any meaningful impact.

\section{THE POOR AS ENTREPRENEURS AND BUSINESS PARTNERS (PRODUCERS AND/OR SUPPLIERS)}

A primary question which comes to mind: are the poor in developing countries more risk-takers as entrepreneurs compared to their richer counterpart? Intuitively, we would say "yes" as absorbing a high risk could be the only way out of poverty. Also, in most underdeveloped countries the bulk of the population at large and the majority of entrepreneurs in particular are very young which further encourages bold business attitude. It is amazing how supporting entrepreneurship can be accomplished by providing funds which from the Western perspective are very small, say $\$ 50$. Yet, this money can buy a small market stall or a basic means of transportation, a rickshaw or a bicycle. In India, the rickshaw would allow a poor rural family to retain 50 percent of the profits from the wheat that would have gone to pay another transporter (Khosla, 2004). Lending to small groups in the same community creates a strong social pressure against failure to pay. It is embarrassing to default, and if one person does, the others have to make up for it.

How to streamline the entrepreneurial activity? One area is production and a way the large corporations (local and foreign) can take the entrepreneurs under their wings is through subcontracting. Specifying what supplies are desirable - crops, medicinal plants, handicrafts — can assure outlets for otherwise misdirected energy. After all, how many African masks or woven hammocks can be sold at the roadside stalls to the visiting tourists? Yet, many of the local craftsmen do not know better how to use their talents. In this context, the strategies and activities of companies like Pier 1 Imports or the Body Shop provide an inspiration. Lifting the shroud of anonymity from the poor suppliers should already prove helpful. Just like when the trading organizations and MNCs emphasize in the developed markets the "natural" character of the ingredients and/or provide the information about the poor communities who are the suppliers of the inputs/raw materials. Such efforts in turn help boost the sales. 
Another form of assistance is to provide farmers with credits to buy yield-enhancing inputs. The resulting increased production and sales can help to repay the loan. Large, agriculture-based companies operating in developing countries like India have not only extended credits but also actively engaged in educating the farmers on how to use their products effectively.

Companies with dual roles of providing resources and knowledge (advice) can be a very attractive option for the poor entrepreneurs in the developing markets. As one author puts it, corporate responsibility must align organizational learning with societal issues to the point that such issues then turn into higher opportunities for both sides (Zadek, 2004). A shift in the managerial mindset is required for this to happen - a shift from the risk-based, reputational view of corporate responsibility to one focused on innovation and knowledge that will help realign the business model and the market according to the "emerging" societal concerns. The giant footwear and apparel company, Nike, has made significant strides to do exactly that. It has joined a group of companies, NGOs and labor organizations to explore how an alliance can help to deal with the challenges of developing programs for workers in sourcing countries as well as establishing a framework to guide companies in re-adjusting supply chain in the postMFA (Multi-Fiber Arrangement) world when all country-based garments quotas will be lifted for the all important US market.

An important objective of the resource deployment of the companies is to improve access for the poor. The economically disadvantaged segment of the population lacks good distribution and communication links. Granting access is a pre-requisite for economic development and the companies involved in business with the poor must address this issue. In other words, it is not just the end product or service but the process through which they will be created and delivered that companies must participate in. This is where the entrepreneurial spirit of the poor business partners can be put to good use, especially when the small scale of undertaking (e.g. street or village vendors) does not require substantial investment. As discussed above, the nature of the poor consumers and their spending patterns require a different type of middlemen capable to distribute in small quantities and quickly attend to the local market needs. Lack of refrigeration compounds the issue regarding the food items. Hence, the opportunity for micro scale business-oriented salespeople operating on a door-to-door or similar basis becomes evident. For instance, a soft drink company such as Coca-Cola can offer not only its products but also the delivery means (manually pulled tricycles) to carry them in remote locations. In yet another example, Grameen Phone in Bangladesh and WorldTel Ltd. in India have introduced the concept of community telephone in rural areas operated by an entrepreneur (usually a woman) who charges a fee for the use of the telephone (Prahalad and Hart, 2002).

\section{THE POOR AS EMPLOYEES}

By providing new jobs, the companies create income opportunities for the poor. In this respect, it is crucial that there is sufficient job security. The importance of steady income as opposed to ad hoc employment cannot be overemphasized. In hiring and subsequent employment, companies have found success more often than not when they have included local community members in the decision process. For example, setting up assessment workshops monitored by community specialists and company human resources personnel for hiring new employees have been quite effective in the Australian diamond mines (WBCSD, 2004). The location of industrial activities in many developing areas determines access to a specific pool of the workforce (the lack of housing limits mobility). Hence, it is also in the best interest of the employer not only to keep workers satisfied but also to help improve their living conditions and enhance their qualifications as a way to reduce the absenteeism and increase productivity. Loyalty and commitment of the employees depend upon the quality of life they are provided with at work and at home. The respective needs can vary from area to area but at a minimum encompass the need for basic infrastructure (to help facilitate transportation to and from work), fair housing standards, access to electricity, clean water, primary health care, and basic education. Correspondingly, the interests of the communities from which the workers are recruited will also be better served. Developing the people and the infrastructure is an essential part of a company's overall strategy in developing countries. As noted by researchers (London and Hart, 2004; Sharma, Vredenburg and Westley, 1994; Prahalad and Hammond, 2002), this element of the MNC's strategy is critical for ultimate success because it helps develop local capacity for the long run by sharing resources across regional boundaries.

It is important to emphasize that one important way to overcome the credit and borrowing limitations witnessed by the poor is by having the employer guarantee the loans. After all, the employers do verify, provide and control the steady flow of income to employees. 
Two other aspects deserve mentioning as well:

1. The use of corporate infrastructure to generate positive externalities benefiting not only own employees but communities at large. Examples include the use of the company clinics to voluntarily screen the public for HIV/AIDS and other illnesses. Further, continuing education need not only be geared towards own workforce but also training (while utilizing own centers) of the local youth in computer and other skills.

2. Involving own employees as volunteers to do the work for the community when implementing the corporate social responsibility projects. The latter trend also helps to address the psychological rift between those who have jobs and the unemployed within a particular commune or village. Adoption of such a "Robin Hood approach" enhances the embedded social capital (Coleman, 1994) and cohesion.

It is not accidental that some of the best practices in dealing with the poor were developed by the corporations deeply rooted in the underdeveloped countries (e.g. Tata Group in India). Some created original and demanding social responsibility standards in following the ideas of the charismatic business owners. In doing so, they proved that the Robert Owen's spirit was (and is) alive and well.

\section{DISCUSSION AND RECOMMENDATIONS FOR RENEWING COMPANY AND GOVERNMENT EFFORTS}

It is our point of view that companies developing strategies for the poor have to include the corporate social responsibility (CSR) view as well. Strictly looking at the poor as customers for making profit is neither hugely attractive nor does it fulfill the socio-economic objective of reducing poverty. In fact, if pursued aggressively, the profit-making objective could lead to charges of exploitation of the poor. Consider the fact that clever marketing by the firms coupled with the lack of education among the poor can lead to buying of products that shouldn't have been bought in the first place. It is not that the poor do not deserve to buy new things but given their limited income a bad judgment may result in a tradeoff of the more important products for a less important one.

Also, large, multinational corporations work in (developing) countries with poor infrastructure and weak socio-economic institutions. The exploitation of the poor and the environment cannot be ignored (Rosen, 2002). Hence, a corporate social responsibility perspective as well as a sustainable development perspective must be included with the business perspective for the BOP segment. The people living at the BOP are heavily dependent on the natural environment and cannot always react appropriately to changes (Hahn, 2008). Agriculture, fishery and livestock are important resources for their livelihood and preserving the environment is a must for the poor to have any chance of success (Stern, 2007). Also, BOP poor can create burden on the environment (Hart, 2005) and, therefore, the reduction of poverty can translate into an effective strategy for sustainability (Hahn, 2008).

Helping the poor essentially means raising their real income. One way to do this is for companies to penetrate the BOP market by offering product at lower prices. To lower prices without significantly reducing the quality of the product means reducing costs of production. Technologies affecting production and distribution have made significant strides but further changes would be necessary to really have an impact on prices. More so, the cost reduction effect must show up in basic food, clothing and shelter where the poor spends the bulk of their income. Healthcare is another area where cost reduction can help the poor but that has yet to be realized. From the market standpoint, technology driven strategy such as the "shared-access" model whereby cell phones are shared by a group of villagers can make products more affordable (Karnani, 2007). All these point to the need for overall development of the economy, with mass industrialization and technology leading the charge to raise the real income of the poor.

We further contend that companies should view the poor primarily as suppliers/producers and employees if poverty is to be reduced. Most of the poor doesn't have the necessary education and/or business means to be a successful entrepreneur. With little capital, low skills, and no scale economies successfully operating in a competitive market with few entry barriers can be quite challenging (Karnani, 2007). The profit margin is expected to be low, if at all. Involved in subsistence activities the majority of the poor still finds it very difficult to break the cycle of poverty. In this regard, some have even questioned the effectiveness of financing schemes such as microcredit for the poor (Khawari, 2004; Morduch, 1998; The Economist, 2006). It is not surprising that most of the poor would prefer to work as an employee rather than try out their luck in business. This supports our earlier argument that rapid industrialization is the best solution to overcome poverty. The poor needs steady jobs with 
reasonable wages to not only fulfill their daily needs but to think long-term, taking care of education and healthcare for their families. China's experience in the last two decades is a prime example where with increased employment the poverty level has continued to drop (Majid, 2005). A large part of it is due to labor-intensive manufacturing where companies have provided steady wages and attempted to increase productivity through scale economies and skill upgrades of the workers (Karnani, 2007). Directly engaging the poor in the productive sectors of the economy, either as a supplier/producer or as an employee will ensure a higher level of real income for them than in any other way.

The role of the government is quite clear in this situation. They have to develop appropriate policies to offer the right infrastructure and institutions to encourage the private sector to create employment and new opportunities. An efficient capital market and good infrastructure (transportation, electricity, etc.), for example, will go a long way to prompt companies to move into previously inaccessible locations in rural areas and offer jobs to the poor. Once again, the Chinese example is a case in point. The government there has directly involved itself (much more than some Western inclined countries) to clearly delineate the work of the public sector to help the poor. A strong and involved government is not a bad idea after all. Leaving it entirely to the private sector has its limitations. Also, without the government's direct involvement, the poor will have no support and minimal rights, and will find it extremely difficult to emerge from poverty. Financial independence along with socio-cultural changes for the poor must be ensured.

For the government to do its job properly the NGOs can play a crucial role. The NGOs can contribute by being an advocate for the poor, bringing into the forefront issues such as empowerment, rights, and financial independence of the poor.

One of the main problems with intensifying social contributions of the corporations and helping the poor in particular is the lack of measures of economic impact. Since it is hard to assess the effectiveness, it is difficult to decide on how many resources to commit. Correspondingly, a practical judgment needs to be made: to what extent helping the poor is a business decision and to what degree it is the issue of conscience. The "feel good" factor can be an important driver but under strong competition and thin margins, capitalism imposes its rules. In that spirit, we recommend that:

1. Realistic expectations are established regarding what private companies can accomplish. However, plenty of room for creativity needs to be allowed. There are many little important things to be done before more ambitious (and more difficult to manage) tasks are undertaken. After all, the strength of the business lies in the creativity to promptly find efficient solutions to the emerging problems. For example, partnering with NGOs and allowing for "piggybacking" on companies' physical and technological infrastructure generates opportunities in the field of education, construction, transportation, and telecommunication. The knowledge and asset bases of the companies can be further utilized to coach potential local entrepreneurs on how to run a successful business. Mentoring will ensure a good local partner for the long run and will increase the likelihood of societal acceptance for the international company.

2. Companies are advised to stick to the programs related to their core business operations -- efficient marketing of product and services and the harmonious co-existence with the communities where they manufacture. To illustrate, large multinational banks have always set up their bases in few major cities in the developing countries serving the rich. They can stick to their core skills but should think of extending their reach to the poor through innovative products and processes.

3. The role of the governments is well defined and diligently performed.

It is with respect to the last point that we offer the concluding remarks. An enabling environment is a prerequisite for business companies to do their share of good deeds. It means that at first clear social priorities need to be announced by the governments (national and local where applicable). This provides guidance for business companies which will act more in sync with the societal goals and earn the rewards they merit. Without the message of clear priorities, the companies might end up mimicking each other in pursuit of one idea: to ingratiate themselves with the government. Today, governments, communities, and civil society increasingly anticipate the companies to become involved with social issues. 
Guidance, responsible fiscal and tax policies, effective programs in the areas of public domain (education, health care), transparency, good governance and business-friendly environment, and efficient judicial system are all important aspects. Because of the elevated risk of some investments (for example, utilities), there is the additional need for government guarantees extended to private business operations.

Since it is first and foremost the role of the governments to promote the national development, the cooperation from business will be enhanced by governments' own "leading by example" approach. It is imperative that good governance, transparency, stability of government practices become a norm. How can one expect businesses to make a serious commitment to the government's cause if at the same time it is plagued by corruption, show-off projects, divisiveness or disregard of political process? What is more, overly complicated, ambiguous, biased policies followed by the government only invite opposition and cheating from business. And obviously, it is not just the central administration but the public sector agencies (central bank, utilities, social security, transportation sector, even police) as well who need to demonstrate leadership as harbingers of caring about the poor -- whether at issue are social benefits for the employees or community at large. Needless to say, public sector represents a big part of GDP in many relevant countries (OECD, 2004b). Apart from the philanthropy-oriented private companies, many more private businesses are motivated by what is expected of them (Schwartz and Carroll, 2003). It might be hard to convince the private enterprises to undertake a relatively greater effort than their stateowned counterparts ${ }^{3}$. In addressing the issue of symbiotic behavior of businesses and governments, the latter should be advised to:

1. Use persuasion and incentives. They seem to work better than coercion.

2. Recognize the contribution businesses make to your economic and social development and reward good action.

Proper understanding of the above stipulations will facilitate spreading out of the "public-private" partnerships (PPPs). Such partnerships involving the business, the government, and the non-governmental organization (NGO) are a must since the challenges of poverty reduction in the developing world are so great that no one sector can "go it alone."

\section{REFERENCES}

1. Akula, V. (2008). Business Basics at the Base of the Pyramid. Harvard Business Review, June: 53-57.

2. Bird, F. \& Smucker, J. (2007). The Social Responsibilities of International Business Firms in Developing Areas. Journal of Business Ethics, 71(1): 1-9.

3. Coleman, J. (1994). Foundations of Social Theory. Cambridge: Harvard University Press.

4. $\quad$ De George, R.T. (1999). Business Ethics. Upper Saddle River, NJ: Prentice Hall.

5. $\quad$ Erle, B. (2004). Junked computers, environmental risks. Baltimore Sun, July 12.

6. Green, S.L. (2001). Export of used equipment, clothing and vehicles including remanufactured automobile parts. Export America, April: 14-15.

7. Hahn, R. (2009). The Ethical Rational of Business for the Poor - Integrating the Concepts Bottom of the Pyramid, Sustainable Development, and Corporate Citizenship. Journal of Business Ethics, 84: 313-324.

8. Hart, S. (2005). Capitalism at the Crossroads - The Unlimited Business Opportunities in Solving the World's Most Difficult Problems. Wharton School Publication, Upper Saddle River, NJ.

9. Karnani, A. (2007). Misfortune at the Bottom of the Pyramid. Greener Management International, 51: 99110 .

10. Karnani, A. (2007). The Mirage of Marketing to the Bottom of the Pyramid: How the Private Sector can help Alleviate Poverty. California Management Review, 49 (4): 90-111.

11. Khawari, A. (2004). Microfinance: Does it Hold Its Promises? A Survey of Recent Literature. Discussion Paper 276, Hamburg Institute of International Economics.

12. Kim, Hak-Su. (2004). Equitable Growth Can Defeat Poverty. Economiquity, (1): 2

13. Khosla, V. (2004). Microlending: An Anti-Poverty Success Story. May, http://www.gsb.stanford.edu/news/headlines/2004globalconf_khosla.shtml.

\footnotetext{
${ }^{3}$ The argument can also apply to foreign investors vs. local companies.
} 
14. Majid, N. (2005). On the Evolution of Employment Structure in Developing Countries. Employment Strategy Papers, International Labor Organization, 2005.

15. Morduch, J. (1998). Does Microfinance Really Help the Poor? New Evidence from Flagship Programs in Bangladesh. Harvard Institute of International Development and Hoover Institution, Stanford University, www.wws.princeton.edu/ rpds/downloads/morduch_microfinance_poor.pd

16. OECD. (2004a). Accelerating Pro-Poor Growth through Support for Private Sector Development: An Analytical Framework. Paris.

17. OECD. (2004b). Guidelines on Corporate Governance of State-Owned Enterprises. Draft Text. http://www.oecd.org/dataoecd/33/31/34051587.pdf

18. Porter, M.E. \& M.R. Kramer. (2002). The Competitive Advantage of Corporate Philanthropy. Harvard Business Review, (Dec): 5-16.

19. Prahalad, C. K. (2004). Fortune at the Bottom of the Pyramid: Eradicating Poverty through Profits. Upper Saddle River, N.J.: Wharton School Publishing.

20. Pralahad, C.K. and A. Hammond. (2002). Serving the World's Poor, Profitably. Harvard Business Review, (Sept): 4-11.

21. PWC (2002). Uncertain Times, Abundant Opportunities. http://www.pwc.com/gx/eng/ins-sol/surveyrep/ceo/PwC_Global_CEO_Survey.pdf

22. Rosen, E. I. (2002). Making Sweatshops: The Globalization of the U.S. Apparel Industry. Berkeley, CA: University of California Press.

23. Schwartz, M. S. \& A. B. Carroll. (2003). Corporate Social Responsibility: A Three-Domain Approach. Business Ethics Quarterly, 13 (4): 503-530.

24. Sharma, S., Vredenburg, H., and Westley, F. (1994). Strategic bridging: a role for the multinational corporation in Third World development. Journal of Applied Behavioral Science, 30(4): 458-476.

25. Stern, N. (2007). The Economics of Climate Change - The Stern Review. Cambridge University Press, Cambridge.

26. The Economist. (2006). Macro Credit. October 19.

27. The World Bank. (2004). World Development Report 2005 - A Better Investment Climate for Everyone. Washington D. C.

28. UN. (2006). The Millennium Development Goals Report 2006. New York, NY.

29. UNCTAD. (2007). The Least Developed Countries Report 2007. New York, NY.

30. UNDP/BC/CII/PWC. (2002). Corporate Social Responsibility Survey 2002-India. New Delhi: 48 pages.

31. WBCSD. (2004). Doing business with the poor - a field guide. Geneva: World Business Council for Sustainable Development: 73 pages.

32. WCED. (1987). Our Common Future. Oxford University Press, Oxford.

33. WEF. (2005). http://www.weforum.org

34. Zadek, S. (2004). The Path to Corporate Responsibility. (Best Practice). Harvard Business Review, December. 